\title{
PENGARUH LIKUIDITAS, LEVERAGE DAN UKURAN PERUSAHAAN TERHADAP FINANCIAL DISTRESS PADA PERUSAHAAN PROPERTI DAN PERUMAHAN
}

\author{
THE EFFECT OF LIQUIDITY, LEVERAGE AND SIZE \\ OF THE COMPANY AGAINST THE FINANCIAL DISTRESS \\ OF PROPERTY AND REAL ESTATE COMPANIES
}

\author{
Stephanie $^{1}$, Lindawati ${ }^{2}$, Suyanni $^{3}$, Christine $^{4}$, Efvina Oknesta $^{5}$, Adam Afiezan ${ }^{6}$ \\ Universitas Prima Indonesia ${ }^{1,2,3,4,5,6}$ \\ adamafiezan@unprimdn.ac.id 6
}

\begin{abstract}
At present the development of property and housing companies is very rapid. The purpose of this research is to be able to determine the effect of Liquidity, Leverage and Company Size on Financial Distress in Property and Real Estate Companies listed on the Indonesia Stock Exchange Period 2013-2017. The approach used is quantitative research. Researchers use secondary data types and sources. The population of this research is 48 Property and Real Estate Companies listed on the Indonesia Stock Exchange in the period 2013-2017. The sample is 29 Property and Housing Companies listed on the Indonesia Stock Exchange for the period 2013-2017 with 145 observational samples. The sampling technique is a purposive sampling method. Data Analysis Technique used is Logistic Regression. The results of this study are liquidity affecting financial distress in Property and Real Estate companies listed on the Indonesia Stock Exchange. Leverage does not affect financial distress in Property and Real Estate companies listed on the Indonesia Stock Exchange. The size of the company does not affect financial distress in Property and Real Estate companies listed on the Indonesia Stock Exchange. Liquidity, leverage and company size affecting financial distress in Property and Estate companies listed on the Indonesia Stock Exchange.
\end{abstract}

Keywords: Liquidity, Leverage, Company Size and Financial Distress

\begin{abstract}
ABSTRAK
Saat sekarang ini perkembangan perusahaan properti dan perumahan sangat pesat. Tujuan dilakukannya penelitian ini untuk dapat mengetahui pengaruh dari Likuiditas, Leverage dan Ukuran Perusahaan terhadap Financial Distress pada Perusahaan Properti dan Perumahan yang terdaftar di Bursa Efek Indonesia Periode 2013-2017. Pendekatan yang digunakan adalah penelitian kuantitatif. Peneliti menggunakan jenis dan sumber data sekunder. Populasi penelitian ini sebanyak 48 Perusahaan Properti dan Perumahan yang terdaftar di Bursa Efek Indonesia periode 2013-2017. Sampelnya sebanyak 29 Perusahaan Properti dan Perumahan yang terdaftar di Bursa Efek Indonesia periode 2013-2017 dengan sampel pengamatan sebanyak 145 observasi pengamatan. Teknik pengambilan sampel adalah metode purposive sampling. Teknik Analisis Data yang digunakan adalah Regresi Logistik. Hasil penelitian ini adalah likuiditas mempengaruhi financial distress pada Perusahaan Properti dan Perumahan yang terdaftar di Bursa Efek
\end{abstract}


Indonesia. Leverage tidak mempengaruhi financial distress pada Perusahaan Properti dan Perumahan yang terdaftar di Bursa Efek Indonesia. Ukuran perusahaan tidak mempengaruhi financial distress pada Perusahaan Properti dan Perumahan yang terdaftar di Bursa Efek Indonesia. Likuiditas, leverage dan ukuran perusahaan mempengaruhi financial distress pada Perusahaan Properti dan Perumahan yang terdaftar di Bursa Efek Indonesia.

Kata Kunci : Likuiditas, Leverage, Ukuran Perusahaan dan Financial Distress

\section{PENDAHULUAN}

Keberhasilan maupun kegagalan perusahaan dalam mempertahankan kelangsungan hidupnya dapat terjadi kapan saja. Perusahaan yang nilainya baik belum terjamin kelangsungan hidupnya. Hal ini dapat terjadi disebabkan oleh ketidaksanggupan perusahaan untuk membayar utang yang jatuh tempo. Perusahaan perlu melakukan penilaian kinerja keuangan untuk mengetahui tingkat keuntungan perusahaan dengan menggunakan metode financial distress. Financial distress terjadi akibat ketidakmampuan entitas untuk membayar utangnya.

Saat sekarang ini perkembangan perusahaan properti dan perumahan sangat pesat. Peneliti melakukan penelitian terhadap perusahaan properti dan perumahan yang terdaftar di Bursa Efek Indonesia dikarenakan investasi dibidang properti dan perumahan memberikan keuntungan di masa depan. Namun perkembangan perusahaan dibidang properti dan perumahan di tahun 2016 hingga tahun 2017 ini menghadapi masalah dimana banyak perumahan dan ruko yang dibangun perusahaan tidak laku terjual. Perumahan yang dibangun perusahaan tidak terjual mengakibatkan laba perusahaan mengalami penurunan dan mengakibatkan perusahaan dalam menghadapi masalah keadaan financial distress (Putra \& Suryanawa, 2016). Adapun financial distress dipengaruhi oleh faktor yaitu rasio likuiditas, leverage dan ukuran perusahaan.
Financial distress dapat terjadi apabila likuiditas perusahaan menurun. Rasio lancar sering dijadikan sebagai indikator likuiditas perusahaan. Apabila semakin besar tingkat rasio lancar suatu perusahaan maka semakin besar pula tingkat perlindungannya. Likuiditas perusahaan tinggi menunjukkan perusahaan tidak dalam keadaan financial distress namun likuiditas rendah dapat mengakibatkan perusahaan dalam keadaan financial distress.

Financial distress sering dihadapi perusahaan memiliki utang tinggi dimana ketidakmampuan perusahaan membayar utang tersebut. Debt to asset ratio menggunakan utang sebagai pembiayaan aktiva perusahaan. Perusahaan yang memiliki leverage tinggi selalu mengakibatkan perusahaan dalam keadaan financial distress (Kalimah, 2017). Hal ini terjadi karena ketidakmampuan perusahaan dalam melunasi utangnya yang tinggi.

Financial distress sering dihadapi oleh perusahaan kecil disebabkan perusahaan kecil sulit untuk mendapatkan pinjaman. Perusahaan besar selalu memiliki kesempatan untuk mendapatkan laba tinggi sedangkan perusahaan kecil kesempatan untuk memperoleh laba besar agak sulit. Kesulitan perusahaan untuk memperoleh laba besar rentan terjadi sehingga mengakibatkan perusahaan dapat berada dalam keadaan bangkrut (Setiawan et al., 2017).

Current ratio (rasio lancar) merupakan salah satu alat ukur 
likuiditas untuk mengetahui kemampuan perusahaan dalam membayar utang jangka pendeknya. Rasio lancar termasuk alat ukur likuiditas dengan mengukur tingkat membayar utang jangka pendek dengan seluruh aktiva lancarnya. Perusahaan memiliki aset lancar lebih rendah dari jumlah utang lancar, maka perusahaan akan mendapat kesulitan dalam membayar utang jangka pendeknya. Hal inilah yang menjadi pemicu terjadinya financial distress (Rahmy, 2015). Perusahaan yang berada dalam masalah likuiditas jika perusahaan tidak mampu dalam menyelesaikan masalah utangnya serta menunjukkan kesulitan keuangan maka hal ini dapat berakibat pada kebangkrutan usaha (bankruptcy). Hasil penelitian Putra et al., (2017) menyatakan Current Ratio Berpengaruh Signifikan Terhadap Prediksi Kebangkrutan.

Rasio leverage merupakan suatu rasio yang berguna untuk mengetahui kesanggupan suatu perusahaan dalam membayar seluruh utangnya. Leverage terjadi karena adanya kegiatan menggunakan dana perusahaan dalam bentuk utang yang berasal dari pihak ketiga (Widhiari \& Merkusiwati, 2015). Leverage sebagai salah satu alat ukur pembiayaan utang atas aktiva perusahaan. Rasio leverage tinggi dapat menyebabkan perusahaan tidak mampu membayar utangnya maka akan mengganggu aktivitas operasional perusahaan dan memungkinkan perusahaan berada didalam keadaan financial distress. Hasil penelitian oleh Noviantari \& Ratnadi (2015) menunjukkan bahwa leverage memiliki pengaruh signifikan terhadap prediksi kebangkrutan.

Ukuran

perusahaan

menggambarkan keseluruhan aktiva perusahaan. Biasanya dikenal dengan firm size. Pengukuran untuk ukuran perusahaan dilakukan pada logaritma jumlah aset perusahaan. Perusahaan berskala besar mudah mendapatkan pinjaman daripada perusahaan berskala kecil (Sopiyan \& Rahayu, 2017). Hal ini diakibatkan perusahaan besar mempunyai tingkat kepercayaan yang lebih besar dari kreditur dibandingkan perusahaan yang berskala kecil. Perusahaan besar juga cenderung lebih terdiversifikasi dan lebih tahan terhadap risiko kebangkrutan. Perusahaan berskala besar dapat meminimalisir risiko kebangkrutan dan dapat menurunkan biaya monitoring dikarenakan perusahaan besar dapat menyediakan informasi yang lebih banyak. Astuti \& Pamudji (2015) dalam penelitiannya mengatakan, semakin besar pula ukuran suatu perusahaan maka resiko financial distress semakin kecil.

Berdasarkan fenomena financial distress yang di dukung dengan kajian empiris dari penelitian-penelitian terdahulu, maka penelitian ini mencoba menganalisa apakah rasio likuiditas, leverage dan ukuran perusahaan memberikan pengaruh signifikan terhadap finansial distress perusahaan property dan perumahan. Namun penelitian yg meneliti financial distress bagi sektor poperty di indonesia masih tergolong kurang.

\section{METODE PENELITIAN}

Teknik pengumpulan data penelitian adalah tinjauan pustaka dan dokumentasi. Tinjauan pustaka yaitu peneliti menggunakan buku rujukan atau buku teks yang berhubungan dengan judul skripsi ini. Dokumentasi penelitian ini memakai laporan keuangan Perusahaan Properti dan Perumahan yang terdaftar di Bursa Efek Indonesia.

Peneliti menggunakan jenis dan sumber data sekunder. Data sekunder 
menggunakan laporan keuangan yang dipublikasikan oleh Bursa Efek Indonesia melalui situs www.idx.co.id, laporan keuangan, jurnal, serta bukubuku referensi yang berkaitan dengan topik penelitian.

Populasi adalah keseluruhan kelompok elemen yang lengkap yang ingin diteliti oleh peneliti. Populasi yang terdapat dalam penelitian ini adalah 48 Perusahaan Properti dan Perumahan yang terdaftar di Bursa Efek Indonesia periode 2013-2017. Adapun teknik pengambilan sampel adalah metode purposive sampling, yaitu pengambilan sampel berdasarkan kriteria tertentu. Berikut kriteria yang digunakan adalah :

1. Perusahaan Properti dan Perumahan yang terdaftar di Bursa Efek Indonesia periode 2013-2017.

2. Perusahaan Properti dan Perumahan yang mempublikasikan laporan keuangan berturut-turut pada Periode 2013-2017.

3. Perusahaan Properti dan Perumahan yang memiliki laba positif pada Periode 2013-2017.

Jumlah sampel penelitian sebanyak 29 Perusahaan Properti dan Perumahan yang terdaftar di Bursa Efek Indonesia periode 2013-2017 dengan sampel pengamatan sebanyak 145 observasi pengamatan.

Penelitian ini memakai regresi logistik disebabkan financial distress ini termasuk variabel dummy. Terlebih dahulu peneliti menggunakan statistik deskriptif untuk menjelaskan keseluruhan sampel, minimum, maximum, mean dan standar deviasi dalam pengujian data penelitian ini. Penelitian ini memakai analisis data regresi logistik. Model regresi logistik berguna untuk menguji terjadinya prediksi variabel dependen terhadap variabel independen, dengan alat ukur 0 atau 1. Secara praktis, model regresi logistik yang digunakan dapat dirumuskan dalam persamaan sebagai berikut:

$\frac{F D}{1-F D}=\mathrm{b}_{0}+\mathrm{b}_{1} \mathrm{X} 1+\mathrm{b}_{2} \mathrm{X}_{2}+\mathrm{b}_{3} \mathrm{X}_{3}+\mathrm{e}$

Dimana :

$$
\begin{array}{lll}
\frac{F D}{1-F D} & =\text { Financial Distress } \\
\mathrm{b}_{0} & =\text { Konstanta } \\
\mathrm{b}_{1}-\mathrm{b}_{2}-\mathrm{b}_{3} & =\quad \text { Koefisien } \\
\text { independen } & \\
\mathrm{X}_{1} & =\text { Likuiditas } \\
\mathrm{X}_{2} & =\text { Leverage } \\
\mathrm{X}_{3} & =\text { Ukuran Perusahaan } \\
\mathrm{E} & =\text { Error }(\alpha=5 \%)
\end{array}
$$

\section{Menilai Keseluruhan Model (Overall Model Fit)}

Pengujian model fit dengan Hosmer and Lemeshow Goodness-of-fit berguna untuk menguji hipotesis nol apakah data empiris cocok atas sesuai dengan model. Jika nilai Hosmer and Lemeshow signifikansi lebih kecil dari 0,05 maka hipotesis nol ditolak dan tidak fit. Sebaliknya tidak signifikan maka hipotesis nol diterima yang artinya menunjukkan data empiris sama dengan model atau model dikatakan fit.

\section{Menguji Kelayakan Model Regresi}

Pengujian persamaan regresi logistik adalah pengujian kelayakan model. Kelayakan model dalam penelitian ini menggunakan Uji Hosmer and Lemeshow Test(Goodness-of-FitTest). Hosmer and Lemeshow's Goodness of Fit Test bertujuan untuk menguji hipotesis nol apakah data empiris cocok atau sesuai antara model dengan data sehingga model dapat dikatakan fit. Penelitian ini dilakukan untuk mengetahui ketepatan dan kecakupan data pada model regresi logistik. Apabila nilai kurang dari 0,05 artinya model regresi logistik tidak menunjukkan kecakupan data, sebaliknya bila nilai lebih dari 0,05 
artinya model regresi logistik menunjukkan kecakupan data.

\section{Menguji Kekuatan Prediksi}

Pengujian multivariate normal distribution tidak mampu dilakukan karena variabel independen adalah campuran antara variabel metrik (kontinyu) dan non-metrik (kategorial). Maka hal ini mampu dianalisis dengan logistic regression karena tidak diperlukannya asumsi normalitas data pada variabel bebasnya. Jadi logistic regression biasanya digubakan jika pengujian multivariate normal distribution tidak mampu dipenuhi.

Pengujian Hipotesis Penelitian Pengujian hipotesis penelitian ini dilakukan dengan pengujian Wald dan Omnibus sebagai berikut :

1. Uji Wald (Parsial). Pengujian hipotesis dengan membandingkan signifikansi $<0,05$ maka dapat dinyatakan variabel bebas berpengaruh secara signifikan pada variabel terikat. Apabila sig > 0,05 maka dapat dikatakan variabel bebas tidak berpengaruh secara signifikan pada variabel terikat.

2. Uji Omnibus (Simultan). Pengujian simultan penelitian ini memakai Omnibus Test of Model Coefficients dengan adanya tingkat signifikan $(\alpha)$ $5 \%$. Apabila hasil pengujian Omnibus Test of Model Coefficients menunjukkan signifikansi, maka semua variabel bebas dapat dimasukkan kedalam model atau dengan kata lain tidak ada variabel yang dikeluarkan dalam model.

3. Koefisien Determinasi (Nagelkerke $R$ Square). Cox dan Snell's $R$ Square termasuk pengukuran $\mathrm{R}^{2}$ pada multiple regression yang biasanya dapat didasarkan pada teknik perkiraan atau estimasi likelihood dengan nilai maksimum uang kurang dari 1 (satu).

\begin{abstract}
Nagelkerke's $R \quad$ square menunjukkan koefisien Cox dan Snell yang berguna untuk memastikan bahwa nilainya menjadi bervariasi dari 0 (nol) sampai 1 (satu). Hal ini dapat dilakukan dengan cara yaitu membagi nilai Cox dan Snell's $R^{2}$ dengan nilai maksimumnya. Nilai Nagelkerke's $R 2$ dapat didefinisikan seperti nilai $\mathrm{R}^{2}$ pada multiple regression.
\end{abstract}

\section{HASIL DAN PEMBAHASAN Pengujian Statistik Deskriptif}

Statistik deskriptif menunjukkan jumlah perusahaan yang diteliti dalam kategori $\mathrm{N}$, nilai masing-masing variabel yang diteliti untuk nilai minimum, maksimum, mean dan standar deviasi. Untuk lebih jelasnya dapat dilihat pada table 4.1 sebagai berikut:

Tabel 1 Statistik Deskriptif

\begin{tabular}{llllll}
\hline & & & & & Std. \\
& N & Minimum & Maximum & Mean & Deviation \\
\hline CR & 145 &, 05 & 8,80 & 2,3720 & 1,66033 \\
\hline DAR & 145 &, 07 &, 79 &, 4066 &, 14910 \\
\hline UK & 145 & 25,89 & 31,67 & 29,3890 & 1,19469 \\
\hline FD & 145 &, 00 & 1,00 &, 9172 &, 27647 \\
\hline
\end{tabular}

Valid N 145

(listwise)

Sumber : Hasil Pengolahan SPSS versi 23 (2019)

Pada tabel 1 di atas menunjukkan bahwa jumlah data yang digunakan dalam penelitian ini adalah laporan keuangan Perusahaan Properti dan Perumahan yang terdaftar di Bursa Efek Indonesia periode 2013-2017 dengan jumlah sampel sebanyak 145 . Berdasarkan data dari tabel 4.1 dapat dijelaskan bahwa:

1. Nilai minimum likuiditas sebesar adalah 0,05 ; nilai maksimum 8,80. Nilai rata-rata (mean) 2,3720 dengan 
standar deviasi standar sebesar 1,66033 .

2. Nilai minimum leverage sebesar adalah 0,07 ; nilai maksimum 0,79 . Nilai rata-rata (mean) 0,4066 dengan standar deviasi standar sebesar 0,14910 .

3. Nilai minimum ukuran perusahaan sebesar adalah 25,89; nilai maksimum 31,67. Nilai rata-rata (mean) 29,3890 dengan standar deviasi standar sebesar 1,19469.

4. Nilai minimum financial distress sebesar adalah 0,00; nilai maksimum 1,00. Nilai rata-rata (mean) 0,9172 dengan standar deviasi standar sebesar 0,27647.

\section{Pengujian Uji Hipotesis}

Pengujian regresi logistik dapat digunakan untuk mengetahui pengaruh variabel bebas terhadap variabel terikat dengan data pengamatan sebanyak 145 laporan keuangan sebagai data pengamatan. Berikut ini tahapan dalam melakukan analisis regresi logistik.

\section{Menguji Kelayakan Model Regresi (Goodness of Fit Test).}

Pengujian kelayakan model regresi dinilai dari hasil nilai Hosmer and Lemeshow test, seperti yang dijelaskan pada tabel dibawah ini:

Tabel 2 Hosmer and Lemeshow Test

\begin{tabular}{|c|c|c|c|}
\hline Step & Chi-square & Df & Sig. \\
\hline 1 & ,081 & 6 & 1,000 \\
\hline
\end{tabular}
(2019)

Dari tabel 2, hasil uji Hosmer and Lemeshow test adalah besarnya nilai Chi-Square sebesar 0,081 dan nilai signifikasi sebesar $0,994(1,000>0,05)$, dimana $\mathrm{H}_{4}$ diterima dan dapat disimpulkan bahwa hasil nilai Hosmer and Lemeshow Goodness of fit test statistics adalah lebih tinggi dari 0.05, sehingga hipotesis nol dapat diterima yang menunjukkan signifikan antara model dengan nilai pengamatannya sehingga Goodness fit model baik karena model mampu memprediksi nilai pengamatannya.

\section{Menguji Keseluruhan Model Fit (Overall Model Fit Test).}

Pengujian dengan keseluruhan model fit pada statistik yang digunakan berdasarkan fungsi likelihood. Pengujian ini mengamati nilai -2 LL pertama dengan -2 LL kedua ditabel iteration history dalam hasil penelitian. Tabel dibawah ini akan menggambarkan hasil dari $-2 \quad \log$ likelihood pertama pada block number $=$ 0 dan hasil dari -2 log likelihood kedua pada block number $=1$, yaitu sebagai berikut :

Tabel 3 Nilai -2 log likelihood (-2 LL Blok number $=0$ )

Iteration History ${ }^{\mathrm{a}, \mathrm{b}, \mathrm{c}}$

\begin{tabular}{|c|c|c|c|c|}
\hline \multirow{2}{*}{\multicolumn{2}{|c|}{ Iteration }} & -2 & $\log$ & Coefficients \\
\hline & & likelihood & & Constant \\
\hline \multirow[t]{5}{*}{ Step 0} & 1 & 90,122 & & 1,669 \\
\hline & 2 & 83,109 & & 2,237 \\
\hline & 3 & 82,784 & & 2,394 \\
\hline & 4 & 82,782 & & 2,405 \\
\hline & 5 & 82,782 & & 2,405 \\
\hline
\end{tabular}

a. Constant is included in the model.

b. Initial -2 Log Likelihood: 82,782

c. Estimation terminated at iteration number 5 because parameter estimates changed by less than ,001. 
Tabel 4 Nilai -2 log likelihood (-2 LL Blok number $=1$ )

Iteration History $^{\text {a,b,c,d }}$

\begin{tabular}{|c|c|c|c|c|c|c|}
\hline \multirow[b]{2}{*}{ Iteration } & & \multirow[b]{2}{*}{-2 Log likelihood } & \multicolumn{4}{|c|}{ Coefficients } \\
\hline & & & Constant & $\mathrm{CR}$ & DAR & UK \\
\hline \multirow{16}{*}{$\begin{array}{l}\text { Step } \\
1\end{array}$} & 1 & 82,085 & 4,861 & ,169 &,- 880 &,- 110 \\
\hline & 2 & 64,602 & 9,307 & ,488 & $-1,989$ &,- 246 \\
\hline & 3 & 53,665 & 13,008 & 1,163 & $-2,568$ &,- 387 \\
\hline & 4 & 42,650 & 17,878 & 2,565 & $-2,827$ &,- 598 \\
\hline & 5 & 33,096 & 32,320 & 4,773 & $-4,620$ & $-1,122$ \\
\hline & 6 & 26,954 & 56,419 & 7,792 & $-7,029$ & $-1,977$ \\
\hline & 7 & 24,212 & 84,933 & 11,164 & $-9,195$ & $-2,991$ \\
\hline & 8 & 23,309 & 112,222 & 14,302 & $-10,762$ & $-3,967$ \\
\hline & 9 & 23,150 & 129,549 & 16,270 & $-11,606$ & $-4,588$ \\
\hline & 10 & 23,143 & 134,004 & 16,786 & $-11,847$ & $-4,747$ \\
\hline & 11 & 23,143 & 134,224 & 16,813 & $-11,861$ & $-4,755$ \\
\hline & 12 & 23,143 & 134,224 & 16,813 & $-11,861$ & $-4,755$ \\
\hline & \multicolumn{6}{|c|}{ a. Method: Enter } \\
\hline & \multicolumn{6}{|c|}{ b. Constant is included in the model. } \\
\hline & \multicolumn{6}{|c|}{ c. Initial -2 Log Likelihood: 82,782} \\
\hline & \multicolumn{6}{|c|}{$\begin{array}{l}\text { d. Estimation terminated at iteration number } 12 \text { because parameter estimates } \\
\text { changed by less than }, 001 \text {. }\end{array}$} \\
\hline
\end{tabular}

Dari tabel 4, terlihat bahwa hasil blok pertama ( Block Number $=0$ ) adalah 90,122 dan dari tabel 4.4, terlihat bahwa hasil blok kedua ( Block Number $=1$ ) adalah 23,143. Hal tersebut artinya konstanta saja tanpa adanya variabel bebas adalah 66,979. Model ini menunjukan bahwa adanya terjadi penurunan Overall Model Fit pada -2 log likelihoodblock number $=0$ ke -2 log likelihoodblock number $=1$ sebesar 9,542. Penurunan likelihood yang terjadi menunjukan secara keseluruhan model regresi logistik yang dipakai dipenelitian ini adalah model yang baik.

\section{Uji Koefisien Determinasi (Nagelkerke R Square)}

Koefisien determinasi dapai dipakai sebagai pedoman untuk mengetahui seberapa besar tingkat variabel terikat akan dipengaruhi oleh variabel bebas. Besarnya pengaruh itu dapat diketahui melalui nilai Nagelkerke $R$ Square.
Tabel 5 Uji Koefisien Determinasi Model Summary (Nagelkerke R Square)

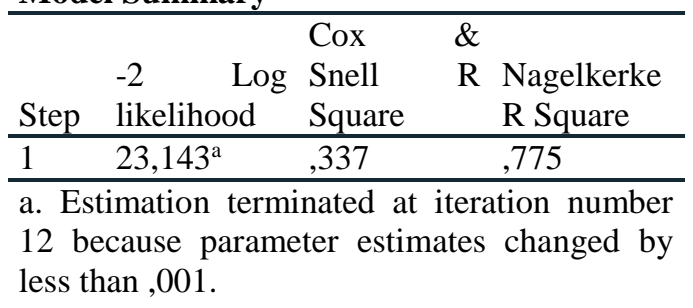

Dari tabel 5, berdasarkan pengolahan data yang menggunakan metode regresi logistik, maka dapat dilihat hasil uji -2 Log likelihood adalah sebesar 23,143 dan hasil nilai nagelkerke $R$ Square dipenelitian ini adalah sebesar 0,775 yang artinya variabilitas variabel dependen yang mampu dijelaskan oleh variabilitas variabel independen adalah sebesar $77,5 \%$, dan sedangkan sisanya sebesar $22,5 \%$ dijelaskan oleh faktor-faktor lain yang tidak ada didalam model.

\section{Omnibus Test of Model Coefficient (Uji Simultan)}

Pengujian omnibus digunakan untuk menguji adanya pengaruh yang secara simultan pada seluruh variabel bebas terhadap variabel terikat. Pengujian dapat dilakukan dengan membandingkan hasil signifikansi ( $p$ value) dan hasil dari Omnibus Tests of Model Coefficients dengan nilai $\alpha$ yang sebesar 0.05 .

Tabel 6 Uji Simultan Omnibus Tests of Model Coefficients

\begin{tabular}{lllll}
\hline & & Chi-square & df & Sig. \\
\hline Step 1 & Step & 59,639 & 3 &, 000 \\
\cline { 2 - 5 } & Block & 59,639 & 3 &, 000 \\
\cline { 2 - 5 } & Model & 59,639 & 3 &, 000 \\
\hline
\end{tabular}

Dari tabel 6, sesuai dengan hasil pengujian regresi logistik diketahui bahwa nilai Chi-square adalah sebesar 59,639 dan degree of freedom sebesar 3. Dengan adanya tingkat signifikasi sebesar 0,000 yang nilainya lebih kecil 
dari 0,05, maka $\mathrm{H}_{4}$ diterima, maka disimpulkan bahwa dengan signifikasi $5 \%$ variabel likuiditas, leverage dan ukuran perusahaan berpengaruh terhadap financial distress pada Perusahaan Properti dan Perumahan yang terdaftar di Bursa Efek Indonesia.

\section{Pengujian Individual/Pengujian Koefisien Regresi(Uji Parsial)}

Pengujian individual penelitian dan menjawab hipotesis yang telah ada sebelumnya, dipakailah tabel variables in the equation yang ada pada output hasil pengolahan data dan disajikan pada tabel 4.7 sebagai berikut :

Tabel 7 Uji Parsial - Wald dan Uji Hipotesis Logistik

Variables in the Equation

\begin{tabular}{llllllll}
\hline & & B & S.E. & Wald & df & Sig. & $\operatorname{Exp(B)}$ \\
\hline Step 1 $^{\text {a }}$ & CR & 16,813 & 6,750 & 6,204 & 1 &, 013 & 20026992,213 \\
\cline { 2 - 8 } & DAR & $-11,861$ & 10,179 & 1,358 & 1 &, 244 &, 000 \\
\cline { 2 - 8 } & UK & $-4,755$ & 2,550 & 3,477 & 1 &, 062 &, 009 \\
\cline { 2 - 7 } & Constant & 134,224 & 70,356 & 3,640 & 1 &, 056 & $1,963 \mathrm{E}+58$ \\
\hline a. Variable(s) entered on step 1: CR, DAR, UK. & &
\end{tabular}

Dari Tabel 7 menunjukkan hasil pengujian hipotesis regresi logistik dengan tingkat signifikansi $5 \%$ atau 0,05 . Dari hasil pengujian diatas, maka akan diperoleh model persamaan regresi logistik dari kolom B sebagai berikut :

$\frac{F D}{1-F D}=134,224+16,813 \mathrm{CR}-11,861 \mathrm{DAR}-4,755 \mathrm{UK}$

Dengan nilai Konstanta yang sebesar 156,416 berarti probabilitas perusahaan berada dalam financial distress. Variabel konstanta model regresi logistik memiliki koefisien positif sebesar 134,224 artinya apabila variabel lain dianggap tetap atau tidak berubah maka financial distress akan mengalami peningkatan sebesar 134,224 satuan.

Variabel likuiditas yang dimiliki oleh perusahaan dimana mempunyai nilai koefisien positif yaitu sebesar 16,813 artinya setiap adanya peningkatan satu (1) pada likuiditas maka akan berada dalam financial distress sebesar 16,813 satuan apabila dengan mengasumsikan variable yang lain sama dengan nol (0). Hasil probabilitas variabel likuiditas sebesar 0,013 yang lebih kecil dari tingkat signifikansi 0,05 (5 persen) yang berarti likuiditas berpengaruh terhadap financial distress pada Perusahaan Properti dan Perumahan yang terdaftar di Bursa Efek Indonesia.

Variabel leverage dimana yang menunjukkan hasil koefisien negatif yaitu sebesar - 11,861 artinya setiap adanya kenaikan satu (1) pada leverage berada dalam financial distress sebesar $-11,861$ satuan dengan mengasumsikan variabel yang lain sama dengan nol (0). Hasil probabilitas variabel leverage sebesar 0,244 yang lebih besar dari tingkat signifikansi 0,05 (5 persen) yang berarti leverage tidak berpengaruh terhadap financial distress pada Perusahaan Properti dan Perumahan yang terdaftar di Bursa Efek Indonesia.

Variabel ukuran perusahaan dimana yang menunjukkan hasil koefisien negatif yaitu sebesar $-4,755$ artinya setiap adanya kenaikan satu (1) pada ukuran perusahaan berada dalam financial distress sebesar -4,755 satuan dengan mengasumsikan variabel yang lain sama dengan nol (0). Hasil probabilitas variabel ukuran perusahaan sebesar 0,062 yang lebih besar dari tingkat signifikansi 0,05 (5 persen) yang berarti bahwa ukuran perusahaan tidak berpengaruh terhadap financial distress pada Perusahaan Properti dan Perumahan yang terdaftar di Bursa Efek Indonesia.

\section{Pengaruh Likuiditas Terhadap Financial Distress}

Hasil dari penelitian ini peneliti menunjukkan bahwa likuiditas berpengaruh terhadap financial distress pada Perusahaan Properti dan 
Perumahan yang terdaftar di Bursa Efek Indonesia.

Hasil penelitian ini sesuai dengan penelitian Rahmayanti \& Hadromi (2017), perusahaan yang berada dalam masalah likuiditas jika perusahaan tidak mampu dalam menyelesaikan masalah utangnya serta menunjukkan kesulitan keuangan maka hal ini dapat berakibat pada kebangkrutan usaha (bankruptcy).

Selain itu, hasil penelitian ini sejalan dengan penelitian Putra et al., (2017) yang menyatakan Current Ratio Berpengaruh Signifikan Terhadap Prediksi Kebangkrutan.

Likuiditas dengan indikator current ratio mempunyai pengaruh positif terhadap financial distress. Likuiditas yang tinggi menunjukkan perusahaan mempunyai aset lancar yang mampu untuk mencakup utang jangka pendeknya, maka kemungkinan perusahaan tidak mampu bayar lebih kecil.

\section{Pengaruh Leverage Terhadap Financial Distress}

Hasil dari penelitian ini peneliti menunjukkan bahwa leverage tidak berpengaruh terhadap financial distress pada Perusahaan Properti dan Perumahan yang terdaftar di Bursa Efek Indonesia.

Hasil penelitian ini tidak sesuai dengan hasil peelitian Rohmadini et al., (2018) berpendapat rasio leverage tinggi dapat menyebabkan perusahaan tidak mampu membayar utangnya maka akan mengganggu aktivitas operasional perusahaan dan memungkinkan perusahaan berada didalam keadaan financial distress.

Perusahaan Properti dan Perumahan yang terdaftar di Bursa Efek Indonesia kebanyakan memakai leverage sebagai modal dalam bentuk utang yang didapatkan dari pihak ketiga.
Perusahaan besar lebih memilih mengandalkan pinjaman bank untuk sebagian besar pembiayaannya.

\section{Pengaruh Ukuran Perusahaan Terhadap Financial Distress}

Hasil dari penelitian ini peneliti menunjukkan bahwa ukuran perusahaan tidak berpengaruh terhadap financial distress pada Perusahaan Properti dan Perumahan yang terdaftar di Bursa Efek Indonesia.

Hasil penelitian ini tidak sesuai dengan penelitian Ananto et al., (2017) dimana perusahaan yang berskala besar biasanya lebih gampang mendapatkan pinjaman daripada perusahaan yang berskala kecil dikarenakan tingkat kepercayaan yang dimiliki oleh kreditur terhadap perusahaan yang berskala besar. Perusahaan yang berskala besar cenderung lebih terdiversifikasi dan lebih tahan terhadap risiko kebangkrutan. Ukuran perusahaan besar juga tidak mampu menghindari masalah kesulitan keuangan dengan melakukan diversifikasi pada usahanya tersebut. Ukuran perusahaan besar sering menggunakan dana pinjaman sebagai modal usahanya.

\section{PENUTUP}

\section{Kesimpulan}

1. Likuiditas berpengaruh terhadap financial distress pada Perusahaan Properti dan Perumahan yang terdaftar di Bursa Efek Indonesia.

2. Leverage tidak berpengaruh terhadap financial distress pada Perusahaan Properti dan Perumahan yang terdaftar di Bursa Efek Indonesia.

3. Ukuran perusahaan tidak berpengaruh terhadap financial distress pada Perusahaan Properti dan Perumahan yang terdaftar di Bursa Efek Indonesia. 
4. likuiditas, leverage dan ukuran perusahaan berpengaruh terhadap financial distress pada Perusahaan Properti dan Perumahan yang terdaftar di Bursa Efek Indonesia

\section{Saran}

Berdasarkan kesimpulan di atas maka peneliti memberikan beberapa saran sebagai berikut :

1. Perusahaan Properti dan Perumahan yang terdaftar di Bursa Efek Indonesia harus memperhatikan faktor pemicu terjadinya financial distress dan segera mengambil tindakan untuk memperbaiki kondisi keuangan perusahaannya.

2. Peneliti selanjutnya disarankan untuk memilih perusahaan lainnya yang digunakan untuk mengetahui faktor yang mempengaruhi kemungkinan terjadinya financial distress.

3. Untuk investor dapat melakukan pengambilan keputusan yang tepat dalam menginvestasikan dananya kedalam perusahaan.

4. Bagi Universitas Prima Indonesia, hasil penelitian ini berguna untuk memperkaya karya ilmiah yang berada dalam perpustakaan Universitas Prima Indonesia.

\section{DAFTAR PUSTAKA}

Ananto, R. P., Mustika, R., \& Handayani, D. (2017). Pengaruh Good Corporate Governance (GCG), Leverage, Profitabilitas dan Ukuran Perusahaan Terhadap Financial Distress Pada Perusahaan Barang Konsumsi yang Terdaftar di Bursa Efek Indonesia. Jurnal Ekonomi dan Bisnis Dharma Andalas, 19(1), 92.
Astuti \& Pamudji. (2015). Analisis Pengaruh Opini Going Concern, Likuiditas, Solvabilitas, Arus Kas, Umur Perusahaan Dan Ukuran Perusahaan Terhadap Kemungkinan Financial Distress. Diponegoro Journal of Accounting, 4(1):1-11.

Kalimah, S. (2017). Pengaruh Profitabilitas, Likuiditas dan Leverage Dalam Memprediksi Financial Distress (Studi Empiris Pada Perusahaan Manufaktur yang Terdaftar di BEI Periode 2009-2013). Jurnal Akuntansi dan Ekonomi, 2(1).

Noviantari, N. W., \& Ratnadi, N. M. D. (2015). Pengaruh financial distress, ukuran perusahaan, dan leverage pada konservatisme akuntansi. E-Jurnal Akuntansi, 646-660.

Putra, I. G. B. B. P., \& Suryanawa, I. K. (2016). Pengaruh Opini Audit dan Reputasi KAP pada Auditor Switching dengan Financial Distress Sebagai Variabel moderasi. E-Jurnal Akuntansi, 1120-1149.

Putra, Y. A. P., Purnamawati, I. G. A., \& Edy Sujana, S. E. (2017). Analisis Rasio Keuangan untuk Memprediksi Kondisi Financial Distress Perusahaan Manufaktur yang Terdaftar di Bursa Efek Indonesia. JIMAT (Jurnal Ilmiah Mahasiswa Akuntansi) Undiksha, 8(2).

Rohmadini, Saifi \& Darmawan. (2018). Pengaruh Profitabilitas, Likuiditas Dan Leverage Terhadap Financial Distress (Studi Pada Perusahaan Food \& Beverage Yang Terdaftar Di Bursa Efek Indonesia Periode 2013-2016). Jurnal Administrasi Bisnis (JAB) 61(2) 
Rahmy, R. (2015). Pengaruh Profitabilitas, Financial Leverage, Sales Growth Dan Aktivitas Terhadap Financial Distress (Studi Empiris pada Perusahaan Manufaktur yang Terdaftar di BEI Tahun 20092012). Jurnal Akuntansi, 3(1).

Rahmayanti, S., \& Hadromi, U. (2017). Analisis Financial Distress Pada Perusahaan Manufaktur Yang Terdaftar di Bursa Efek Indonesia. Jurnal Akuntansi dan Ekonomika, 7(1), 53-63.

Setiawan, D., Oemar, A., \& Pranaditya, A. (2017). Pengaruh Laba, Arus Kas, Likuiditas Perusahaan, Ukuran Perusahaan, Leverage, Kepemilikan Institusional Dan Kepemilikan Manajerial Untuk Mempredikasi Kondisi Financial Distress (Pada Perusahaan Manufakture Yang Terdapat di BEI Periode Tahun 20102015). Journal Of Accounting, 3(3).

Sopian, D., \& Rahayu, W. P. (2017). Pengaruh Rasio Keuangan dan Ukuran Perusahaan Terhadap Financial Distress (Studi Empiris pada Perusahaan Food and Beverage di Bursa Efek Indonesia). COMPETITIVE, 1 (2 ).

Widhiari, N. L. M. A., \& Merkusiwati, N. K. L. A. (2015). Pengaruh rasio likuiditas, leverage, operating capacity, dan sales growth terhadap financial distress. E-Jurnal Akuntansi, 456-469. 